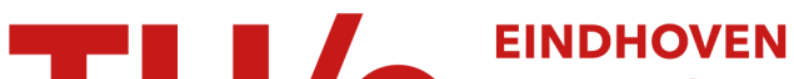 \\ UNIVERSITY OF \\ TECHNOLOGY
}

\section{Thermodynamics of Alon II : phase relations}

Citation for published version (APA):

Willems, H. X., Hendrix, M. R. M. M., With, de, G., \& Metselaar, R. (1992). Thermodynamics of Alon II : phase relations. Journal of the European Ceramic Society, 10(4), 339-346. https://doi.org/10.1016/0955-

2219(92)90089-V

DOI:

10.1016/0955-2219(92)90089-V

Document status and date:

Published: 01/01/1992

Document Version:

Publisher's PDF, also known as Version of Record (includes final page, issue and volume numbers)

Please check the document version of this publication:

- A submitted manuscript is the version of the article upon submission and before peer-review. There can be important differences between the submitted version and the official published version of record. People interested in the research are advised to contact the author for the final version of the publication, or visit the $\mathrm{DOI}$ to the publisher's website.

- The final author version and the galley proof are versions of the publication after peer review.

- The final published version features the final layout of the paper including the volume, issue and page numbers.

Link to publication

\section{General rights}

Copyright and moral rights for the publications made accessible in the public portal are retained by the authors and/or other copyright owners and it is a condition of accessing publications that users recognise and abide by the legal requirements associated with these rights.

- Users may download and print one copy of any publication from the public portal for the purpose of private study or research.

- You may not further distribute the material or use it for any profit-making activity or commercial gain

- You may freely distribute the URL identifying the publication in the public portal.

If the publication is distributed under the terms of Article $25 \mathrm{fa}$ of the Dutch Copyright Act, indicated by the "Taverne" license above, please follow below link for the End User Agreement:

www.tue.nl/taverne

Take down policy

If you believe that this document breaches copyright please contact us at:

openaccess@tue.nl

providing details and we will investigate your claim. 


\title{
Thermodynamics of Alon II: Phase Relations
}

\author{
H. X. Willems, M. M. R. M. Hendrix, G. de With* \& R. Metselaar \\ Centre for Technical Ceramics, P.O.B. 595, 5600 AN Eindhoven, The Netherlands
}

(Received 25 September 1991; revised version received 10 December 1991; accepted 23 December 1991)

\begin{abstract}
The dependence of the lattice parameter of $\gamma$ aluminium oxynitride (Alon) on its composition was investigated. It was found that the width of the homogeneity of Alon varies with temperature: at $1850^{\circ} \mathrm{C}$ Alon is the stable phase between $66 \mathrm{~mol} \%$ $\mathrm{Al}_{2} \mathrm{O}_{3}$ (lattice parameter $0.7953 \mathrm{~nm}$ ) and $81 \mathrm{~mol} \%$ $\mathrm{Al}_{2} \mathrm{O}_{3}$ (lattice parameter $0.7932 \mathrm{~nm}$ ). This region becomes smaller with lower temperatures. Below $1640 \pm 10^{\circ} \mathrm{C}$ Alon is not stable.
\end{abstract}

Es wurde die Abhängigkeit der Gitterparameter von $\gamma$-Aluminiumoxynitrid (Alon) von der Zusammensetzung untersucht. Hierbei konnte festgestellt werden, daß die Breite des Homogenitätsbereiches von Alon mit der Temperatur variiert: bei $1850^{\circ} \mathrm{C}$ ist Alon im Bereich zwischen $66 \mathrm{Mol} \% \mathrm{Al}_{2} \mathrm{O}_{3}$ (Gitterparameter: $0.7953 \mathrm{~nm}$ ) und $81 \mathrm{Mol} \% \mathrm{Al}_{2} \mathrm{O}_{3}$ (Gitterparameter: $0.7932 \mathrm{~nm}$ ) stabil. Die Ausdehnung dieses Bereiches nimmt mit fallender Temperatur ab. Unterhalb $1640 \pm 10^{\circ} \mathrm{C}$ ist Alon nicht stabil.

La dépendance des paramètres de réseau du nitrure d'oxyde d'aluminium $\gamma$ (Alon) par rapport à sa composition a été étudiée. Il a été trouvé que la largeur du domaine homogène de l'Alon varie avec la température: à $1850^{\circ} \mathrm{C}$ l'Alon est une phase stable pour une composition variant entre $66 \mathrm{~mol}^{\circ} \% \mathrm{~d}^{\prime} \mathrm{Al}_{2} \mathrm{O}_{3}$ (paramètre de réseau $0,7953 \mathrm{~nm}$ ) et $81 \mathrm{~mol}^{\circ} \mathrm{d}^{\prime} \mathrm{Al}_{2} \mathrm{O}_{3}$ (paramètre de réseau $0,7932 \mathrm{~nm}$ ). Ce domaine devient plus petit à plus basse température. En dessous de $1640 \pm 10^{\circ} \mathrm{C}$, l'Alon n'est plus stable.

\section{Introduction}

In the literature on $\gamma$-aluminium oxynitride (Alon) there seems to be some disagreement about the

* Also affiliated with Philips Research Laboratories, P.O.B 80000,5600 JA Eindhoven, The Netherlands. width of the stability region of this compound. Results from original research by various authors are summarized in Table 1.

As indicated in a companion paper, ${ }^{1}$ some of the differences observed arise from the fact that Alon is stable only under a very restricted set of oxygen and nitrogen pressures and that it is not stable down to room temperature. One of the problems encountered when trying to establish the width of the homogeneity region of Alon is that the oxygen pressure under which Alon is stable is very low (about $10^{-16}$ bar) and this is very difficult to obtain experimentally. A second problem is that reaction rates are slow at temperatures below $1750^{\circ} \mathrm{C}$ and therefore it becomes difficult to obtain equilibrium.

For these reasons the furnace, the crucible and the process used influence the width of the homogeneity region found experimentally. If a furnace with graphite heating elements with a nitrogen atmosphere is used, some AlN will be made in the course of the process. In that case, it is possible that a sample initially containing too much $\mathrm{Al}_{2} \mathrm{O}_{3}$ (initial composition outside the homogeneity region) is within the homogeneity region after sintering. If a furnace is used in which no reducing agent is present, the results could be the other way around.

In this investigation, the authors have tried to establish the width of the Alon region in the pseudobinary $\mathrm{Al}_{2} \mathrm{O}_{3}-\mathrm{AlN}$ system. Reactions were carried out in atmospheres with high and low partial oxygen pressures to study the influence of the atmosphere on the width and the position of the homogeneity region of Alon.

\section{Experiments}

Alon was synthesized by carbonitridation of aluminium oxide and by reacting aluminium oxide and aluminium nitride in a nitrogen atmosphere.

Journal of the European Ceramic Society 0955-2219/92/\$5.00 (C) 1992 Elsevier Sciences Publishers Ltd, England. Printed in Great Britain 
Table 1. Literature overview of the width of the Alon stability range

\begin{tabular}{lccc}
\hline Authors & $\begin{array}{c}\text { Temperature } \\
\left({ }^{\circ} \mathrm{C}\right)\end{array}$ & $\begin{array}{c}\text { Spinel range } \\
\left(\mathrm{mol}^{\circ} \mathrm{Al}_{2} \mathrm{O}_{3}\right)\end{array}$ & Reference \\
\hline Lejus & 1700 & $67-84$ & 1 \\
McCauley & 1975 & $60-73$ & 2 \\
Guillo & & $68-82$ & 3 \\
Takebe et al. & 1700 & $68-72$ & 4 \\
& 1800 & $66-80$ & \\
\hline
\end{tabular}

Mixtures of $\mathrm{Al}_{2} \mathrm{O}_{3}$ (Rubis synthétique des Alpes, Jarrie, France, A15Z) with AlN (H. C. Starck, Berlin, grade $\mathrm{C}$ ) and with carbon (Cabot, Rozenburg, The Netherlands, Elftex 125) were made in a Turbula T2C mixer (W. A. Bachofen, Basle, Switzerland). The $\mathrm{Al}_{2} \mathrm{O}_{3} / \mathrm{C}$ mixtures contained $74 \mathrm{w} \% \mathrm{Al}_{2} \mathrm{O}_{3}$ and the $\mathrm{Al}_{2} \mathrm{O}_{3} / \mathrm{AlN}$ mixtures contained between 25 and $89 \mathrm{~mol} \% \mathrm{Al}_{2} \mathrm{O}_{3}$. At first, both types of powder were dry mixed in polyethylene flasks with nylon balls. Later the $\mathrm{Al}_{2} \mathrm{O}_{3} / \mathrm{AlN}$ powders were mixed in polyethylene flasks, using silicon nitride balls and isopropanol ('wet mixing').

The mixed powders were pressed uniaxially at $10 \mathrm{MPa}$ into tablets $12 \mathrm{~mm}$ in diameter and $10 \mathrm{~mm}$ in height. These tablets were then pressed isostatically: the dry mixed $\mathrm{Al}_{2} \mathrm{O}_{3} / \mathrm{AlN}$ tablets at $100 \mathrm{MPa}$ and the other tablets at $250 \mathrm{MPa}$. After pressing the surface layer of the tablets was removed by careful polishing.

$\mathrm{X}$-ray diffraction (XRD) was used to measure the ratio of $\mathrm{Al}_{2} \mathrm{O}_{3}$ and $\mathrm{AlN}$ in the unreacted aluminium oxide/aluminium nitride tablets (using a Rigaku DMAX II/C and $\mathrm{Cu} K_{x}$ radiation). For this purpose, the heights of the 104 peak of $\mathrm{Al}_{2} \mathrm{O}_{3}$ and the 002 peak of AlN (lattice spacings of 0.2552 and $0.2490 \mathrm{~nm}$ respectively) were determined. These peaks were chosen because they are fairly strong and close to each other (the latter minimizes the influences of the diffractometer). The peaks were scanned near the summit, using steps of $0.01^{\circ}(2 \theta)$ and a time of $50 \mathrm{~s}$ per step. The maximum number of counts for one step was taken to be the height of the peak.

Reactions were carried out in various furnaces (see Table 2). Sintered tablets were analysed using $\mathrm{XRD}$ to determine the phases present and the lattice parameter of Alon (if present). The lattice parameter was determined by plotting the lattice parameter calculated from the position of each reflection against the function $f(\theta)$, which is given by:

$$
f(\theta)=\frac{\cos ^{2}(\theta)}{\sin (\theta)}+\frac{\cos ^{2}(\theta)}{\theta}
$$

and extrapolating to $f(\theta)=0$ (sec e.g. Cullity ${ }^{2}$ for the details of this procedure). Reflections in the range 70 to $125^{\circ}(2 \theta)$ were used for these calculations. Diagrams were made at $4^{\circ}(2 \theta) \mathrm{min}^{-1}$, except for some cases in which the Alon peaks were very weak and diagrams were made by step scanning with $6 \mathrm{~s}$ $0.01^{\circ}(2 \theta)^{-1}$.

Whenever $\mathrm{Al}_{2} \mathrm{O}_{3}$ or $\mathrm{AlN}$ was found in a reaction sintered sample it was used as an internal standard. For this purpose, the procedure mentioned was used to determine the lattice parameter of $\mathrm{Al}_{2} \mathrm{O}_{3}$ or $\mathrm{AlN}$. Because these substances are hexagonal, use was made of the $c / a$ ratio from the JCPDS to determine the $a$ value. The value for the $a$ parameter thus obtained never differed more than $10^{-4} \mathrm{~nm}$ from the value given in the JCPDS. Therefore the uncertainty of lattice parameters measured in this way is estimated to be $10^{-4} \mathrm{~nm}$.

$\mathrm{Al}_{2} \mathrm{O}_{3} / \mathrm{C}$ and wet-mixed $\mathrm{Al}_{2} \mathrm{O}_{3} / \mathrm{AlN}$ tablets were reaction sintered in the high-frequency furnace at temperatures between 1570 and $1800^{\circ} \mathrm{C} . \mathrm{Al}_{2} \mathrm{O}_{3} / \mathrm{AlN}$ tablets used for these experiments contained $66 \mathrm{~mol} \% \mathrm{Al}_{2} \mathrm{O}_{3}$. The sintering time for experiments in this furnace was $1 \mathrm{~h}$. A graphite crucible was used without a powder bed. After sintering, the $\mathrm{Al}_{2} \mathrm{O}_{3} / \mathrm{C}$

Table 2. Furnaces used for the experiments

\begin{tabular}{|c|c|c|c|}
\hline Furnace & Code & $\begin{array}{l}\text { Heating } \\
\text { elements }\end{array}$ & Atmosphere \\
\hline Gas-pressure & GPSF $^{a}$ & Graphite & Nitrogen (stationary) ( 3 and 80 bar) \\
\hline Tungsten & $\mathrm{ASF}^{b}$ & Tungsten & Nitrogen/hydrogen $(88 \% / 12 \%, 1$ bar $)$ \\
\hline High-frequency & $\mathrm{HFF}^{c}$ & Graphite & Nitrogen (1 bar) \\
\hline Vertical tube & $\mathrm{VTF}^{d}$ & $f$ & Nitrogen ( 1 bar) \\
\hline Horizontal tube & $\mathrm{HTF}^{e}$ & $f$ & Nitrogen (1 bar) \\
\hline
\end{tabular}

${ }^{a}$ KCE Sondermachinen GmbH, type FPW 100/150-2200-100DIL (Rödenthal, Germany).

${ }^{b}$ Astro (Thermal Technology Inc.), type 1100V-4080-W2 (Santa Rosa, California, USA).

' Philips, type PH 1012 (Eindhoven, The Netherlands).

¿ Purpose built by Isoheat (Worksop, UK).

${ }^{e}$ Heracus GmbH, type R0S4/50 (Hanua, Germany).

${ }^{f}$ Elements on the outside of an aluminium oxide tube. 
tablets were ground in an $\mathrm{Al}_{2} \mathrm{O}_{3}$ mortar and the resulting powders were analysed. The $\mathrm{Al}_{2} \mathrm{O}_{3} / \mathrm{AlN}$ tablets were cut, polished on diamond discs and analysed.

In the vertical tube furnace wet-mixed $\mathrm{Al}_{2} \mathrm{O}_{3} / \mathrm{AlN}$ tablets containing $73 \mathrm{~mol} \%$ of $\mathrm{Al}_{2} \mathrm{O}_{3}$ were sintered in two ways. In the first case, an $\mathrm{Al}_{2} \mathrm{O}_{3}$ crucible without a powder bed, in the second a carbon crucible with a thin layer of carbon powder in it was used as a container. Both times the sintering temperature was $1750^{\circ} \mathrm{C}$ and the time was $3 \mathrm{~h}$. The samples were cut in two and both the inside (polished) and the outside (not polished) were analysed.

Dry-mixed $\mathrm{Al}_{2} \mathrm{O}_{3} / \mathrm{AlN}$ tablets were reaction sintered in the vertical tube furnace at temperatures between 1600 and $1750^{\circ} \mathrm{C}$ and times between 5 and $100 \mathrm{~h}$. Wet-mixed $\mathrm{Al}_{2} \mathrm{O}_{3} / \mathrm{AlN}$ tablets were sintered in the tungsten furnace at temperatures of 1800 (for $1 \mathrm{~h}$ ) and $1850^{\circ} \mathrm{C}$ (for 1,3 and $6 \mathrm{~h}$ ) and in the gas pressure furnace at temperatures of $1800^{\circ} \mathrm{C}$ and $1850^{\circ} \mathrm{C}$ (for $1 \mathrm{~h}$ ). See Fig. 1 for an overview of the compositions and temperatures used for the experiments in the vertical tube furnace, the tungsten furnace and the gas pressure furnace. In most of these experiments a powder bed consisting of $\mathrm{Al}_{2} \mathrm{O}_{3}$, AIN and $\mathrm{BN}\left(75 \mathrm{wt} \%\right.$ of a $73 / 27 \mathrm{~mol}^{2} \mathrm{Al}_{2} \mathrm{O}_{3} / \mathrm{AIN}$ mixture and $25 \mathrm{w} \%$ of $\mathrm{BN}$ ) was used to minimize the influence of the surroundings. In the vertical tube furnace a carbon crucible was used, in the tungsten and the gas pressure furnaces a boron nitride crucible was used. After sintering, the samples from the vertical tube furnace were each cut in half, polished and analysed. The samples sintered in the tungsten furnace and the gas pressure furnace had

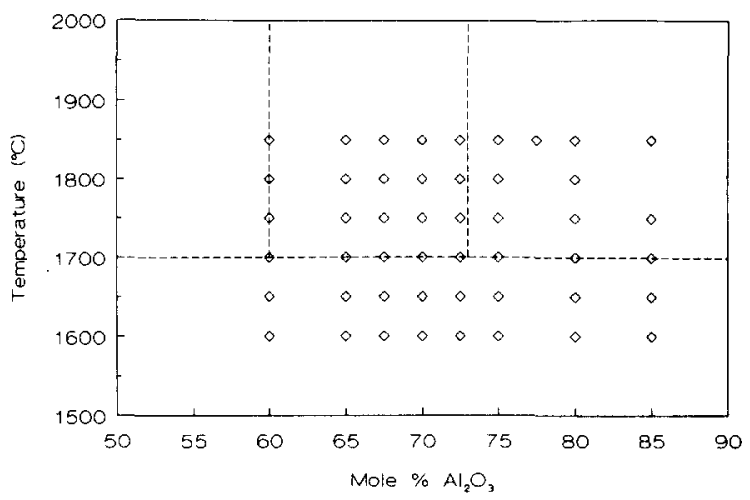

Fig. 1. Overview of the experiments in the vertical tube furnace, the tungsten furnace and the gas pressure furnace. The broken lines are from the Alon phase diagram given by McCauley \& Corbin. $^{9}$

their surface layers removed and were then polished and analysed.

Samples of single-phase Alon (synthesized at $1800^{\circ} \mathrm{C}$ from wet-mixed $\mathrm{Al}_{2} \mathrm{O}_{3} / \mathrm{AlN}$ tablets with $73 \mathrm{~mol} \% \mathrm{Al}_{2} \mathrm{O}_{3}$ ) were annealed in the horizontal tube furnace at a temperature of $1450^{\circ} \mathrm{C}$, using a glassy carbon crucible with a layer of carbon powder in it. After annealing for $100 \mathrm{~h}$ the surface of the samples was analysed.

The conditions for all experiments are summarized in Table 3.

\section{Results}

The $\mathrm{Al}_{2} \mathrm{O}_{3} / \mathrm{AlN}$ ratio of the unreacted tablets can be measured with XRD with an accuracy of about $2 \mathrm{~mol} \% \quad \mathrm{Al}_{2} \mathrm{O}_{3}$. Dry- and wet-mixed $\mathrm{Al}_{2} \mathrm{O}_{3} / \mathrm{AlN}$ tablets gave identical results; therefore, the wet mixing does not influence the $\mathrm{Al}_{2} \mathrm{O}_{3} / \mathrm{AIN}$ ratio.

Table 3. Overview of the experiments

\begin{tabular}{|c|c|c|c|c|c|c|c|c|c|}
\hline $\begin{array}{l}\text { Starting } \\
\text { materials }\end{array}$ & $\begin{array}{c}\mathrm{Al}_{2} \mathrm{O}_{3} \\
(\mathrm{~mol} \%)\end{array}$ & Mixing & $\begin{array}{c}\text { Furnace } \\
\text { code }\end{array}$ & $\begin{array}{c}\text { Sintering } \\
\text { time } \\
(h)\end{array}$ & $\begin{array}{c}\text { Sintering } \\
\text { temperature } \\
\left({ }^{\circ} \mathrm{C}\right)\end{array}$ & Crucible & $\begin{array}{c}\text { Powder } \\
\text { bed }\end{array}$ & Atmosphere & Result \\
\hline $\mathrm{Al}_{2} \mathrm{O}_{3} / \mathrm{C}$ & $\mathrm{N} / \mathrm{A}$ & Dry & HFF & 1 & $1570-1800$ & $\mathrm{C}$ & - & Flowing $\mathrm{N}_{2}$ & Table 5 \\
\hline $\mathrm{Al}_{2} \mathrm{O}_{3} / \mathrm{AIN}$ & 66 & Wet & HFF & 1 & $1630-1650$ & C & - & Flowing $\mathrm{N}_{2}$ & Table 5 \\
\hline $\mathrm{Al}_{2} \mathrm{O}_{3} / \mathrm{AlN}$ & 73 & Wet & VTF & 3 & 1750 & $\mathrm{Al}_{2} \mathrm{O}_{3}$ & - & Flowing $\mathrm{N}_{2}$ & Table 6 \\
\hline $\mathrm{Al}_{2} \mathrm{O}_{3} / \mathrm{AlN}$ & 73 & Wet & VTF & 3 & 1750 & $\mathrm{C}$ & - & Flowing $\mathrm{N}_{2}$ & Table 6 \\
\hline $\mathrm{Al}_{2} \mathrm{O}_{3} / \mathrm{AlN}$ & $60-85$ & Dry & VTF & 100 & 1600 & $\mathrm{C}$ & + & Flowing $\mathrm{N}_{2}$ & in text \\
\hline $\mathrm{Al}_{2} \mathrm{O}_{3} / \mathrm{AIN}$ & $60-85$ & Dry & VTF & 40 & 1650 & $\mathrm{C}$ & + & Flowing $\mathrm{N}_{2}$ & Fig. 3(a) \\
\hline $\mathrm{Al}_{2} \mathrm{O}_{3} / \mathrm{AIN}$ & $60-85$ & Dry & VTF & 100 & 1700 & $\mathrm{C}$ & + & Flowing $\mathrm{N}_{2}$ & Fig. 3(a) \\
\hline $\mathrm{Al}_{2} \mathrm{O}_{3} / \mathrm{AIN}$ & $60-85$ & Dry & VTF & 5 & 1750 & $\mathrm{C}$ & + & Flowing $\mathrm{N}_{2}$ & Fig. 3(a) \\
\hline $\mathrm{Al}_{2} \mathrm{O}_{3} / \mathrm{AlN}$ & $60-85$ & Dry & VTF & 30 & 1750 & $\mathrm{C}$ & + & Flowing $\mathrm{N}_{2}$ & Fig. 3(a) \\
\hline $\mathrm{Al}_{2} \mathrm{O}_{3} / \mathrm{AlN}$ & $60-80$ & Wet & $\mathrm{ASF}$ & 1 & 1800 & $\mathrm{BN}$ & + & Flowing $\mathrm{N}_{2} / \mathrm{H}_{2}$ & Fig. 3(b) \\
\hline $\mathrm{Al}_{2} \mathrm{O}_{3} / \mathrm{AlN}$ & $60-80$ & Wet & ASF & 1 & 1850 & $\mathrm{BN}$ & + & Flowing $\mathrm{N}_{2} / \mathrm{H}_{2}$ & Fig. 3(b) \\
\hline $\mathrm{Al}_{2} \mathrm{O}_{3} / \mathrm{AlN}$ & $60-85$ & Wet & $\mathrm{ASF}$ & 3 & 1850 & $\mathrm{BN}$ & + & Flowing $\mathrm{N}_{2} / \mathrm{H}_{2}$ & Fig. 3(b) \\
\hline $\mathrm{Al}_{2} \mathrm{O}_{3} / \mathrm{AlN}$ & $60-85$ & Wet & ASF & 6 & 1850 & $\mathrm{BN}$ & + & Flowing $\mathrm{N}_{2} / \mathrm{H}_{2}$ & Fig. 3(b) \\
\hline $\mathrm{Al}_{2} \mathrm{O}_{3} / \mathrm{AlN}$ & $60-75$ & Wet & GPSF & 1 & 1800 & BN & + & $\mathrm{N}_{2}$ (stationary) 3 bar & Fig. 3(b) \\
\hline $\mathrm{Al}_{2} \mathrm{O}_{3} / \mathrm{AIN}$ & $60-75$ & Wet & GPSF & 1 & 1850 & $\mathrm{BN}$ & + & $\mathrm{N}_{2}$ (stationary) 3 bar & Fig. 3(b) \\
\hline Alon & $(73)$ & $\mathrm{N} / \mathrm{A}$ & HTF & 100 & 1450 & Glassy C & - & Flowing $\mathrm{N}_{2}$ & in text \\
\hline
\end{tabular}




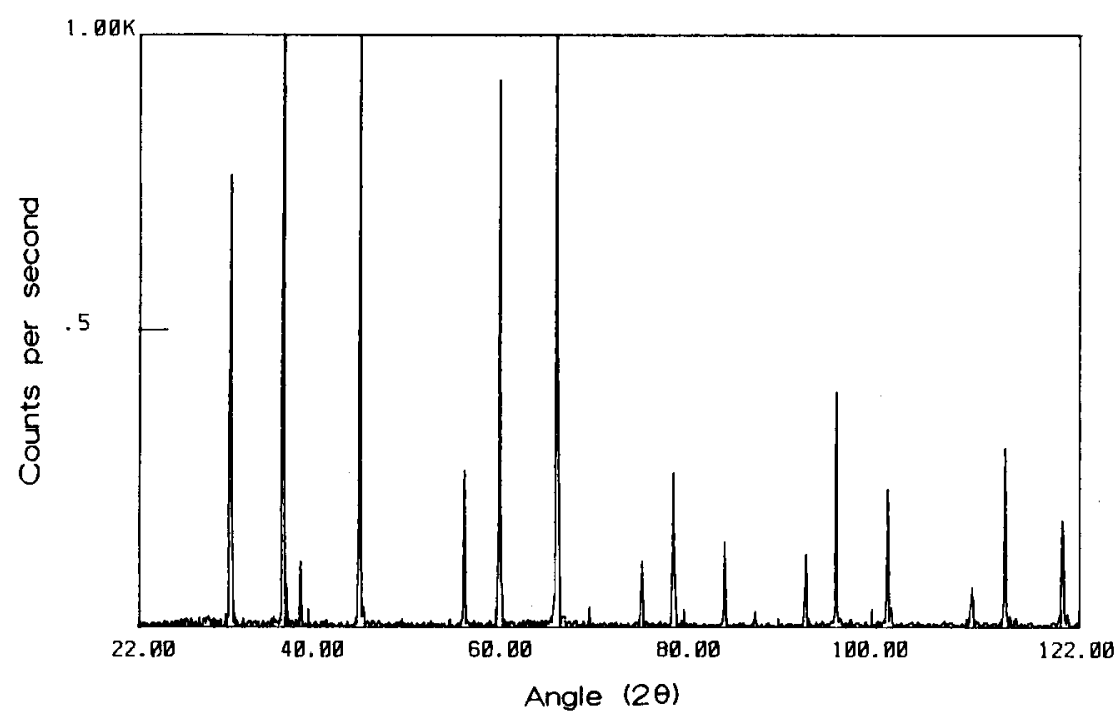

Fig. 2. Diffraction pattern of Alon ( $\mathrm{Cu}-K_{\alpha}$ radiation).

A typical X-ray diffraction pattern of Alon is shown in Fig. 2. As can be seen, the peaks are very sharp and allow an accurate determination of the lattice parameter. The reflections attributed to Alon are summarized in Table 4 . In this table the reflections that were used to calculate the lattice parameter (provded they were found in the diagram) have a 'yes' in the last column. The reflections at

Table 4. Reflections attributed to Alon with a lattice parameter of $0.7950 \mathrm{~nm}$. The last column indicates whether the reflection was used in the calculation of the lattice parameter

\begin{tabular}{|c|c|c|c|c|c|c|}
\hline$H$ & $K$ & $L$ & $d$-value & $2 \theta$ & $I / I_{0}$ & $\begin{array}{c}\text { Reflection } \\
\text { used? }\end{array}$ \\
\hline 1 & 1 & 1 & $4 \cdot 5899$ & $19 \cdot 32$ & 5 & No \\
\hline 2 & 2 & 0 & $2 \cdot 8107$ & $31 \cdot 81$ & 35 & No \\
\hline 3 & 1 & 1 & $2 \cdot 3970$ & $37 \cdot 49$ & 100 & No \\
\hline 2 & 2 & 2 & $2 \cdot 2950$ & $39 \cdot 22$ & $\because 6$ & No \\
\hline 4 & 0 & 0 & 1.9875 & $45 \cdot 60$ & 60 & No \\
\hline 4 & 2 & 2 & $1 \cdot 6228$ & 56.67 & 13 & No \\
\hline 3 & 3 & 38 & 1.5300 & $60 \cdot 46$ & 40 & No \\
\hline 5 & 1 & 1 & & & & \\
\hline 4 & 4 & 0 & 1.4054 & $66 \cdot 47$ & 61 & No \\
\hline 5 & 3 & 1 & 1.3438 & $69 \cdot 95$ & 1 & Yes \\
\hline 6 & 2 & 0 & 1.2570 & $75 \cdot 58$ & 5 & Yes \\
\hline 5 & 3 & 3 & 1.2124 & 78.89 & 10 & Yes \\
\hline 4 & 4 & 4 & $1 \cdot 1475$ & $84 \cdot 33$ & 6 & Yes \\
\hline 5 & 5 & 18 & $1 \cdot 1132$ & $87 \cdot 56$ & 1 & Yes \\
\hline 7 & 1 & 1 & & & & \\
\hline 6 & 4 & 2 & 1.0624 & $92 \cdot 94$ & 7 & Yes \\
\hline 7 & 3 & $1 \&$ & 1.0350 & $96 \cdot 18$ & 15 & Yes \\
\hline 5 & 5 & 3 & & & & \\
\hline 8 & 0 & 0 & 0.9938 & $101 \cdot 63$ & 9 & Yes \\
\hline $\begin{array}{l}8 \\
6\end{array}$ & $\begin{array}{l}2 \\
6\end{array}$ & $\begin{array}{l}2 \& \\
0\end{array}$ & 0.9369 & $110 \cdot 60$ & 2 & Yes \\
\hline 5 & 5 & $5 \&$ & $0 \cdot 9180$ & 114.08 & 14 & Yes \\
\hline 7 & 5 & 1 & & & & \\
\hline 8 & 4 & 0 & 0.8888 & $120 \cdot 13$ & 7 & Yes \\
\hline 6 & 6 & 4 & 0.8475 & $130 \cdot 70$ & 4 & No \\
\hline 9 & 3 & 1 & 0.8334 & $135 \cdot 11$ & 12 & No \\
\hline 8 & 4 & 4 & 0.8114 & $143 \cdot 35$ & 17 & No \\
\hline
\end{tabular}

angles lower than $68^{\circ}$ are not used, because the value derived from them is too inaccurate. The reflections at angles higher than $125^{\circ}$ were not used for the calculations because they did not increase the accuracy.

The results from the experiments in the high frequency furnace are summarized in Table 5 . A ' + ' indicates that Alon was found, $\mathrm{a}^{\text {' }}-$ ' that it could not be found with XRD. AlN was found to form in all experiments with $\mathrm{Al}_{2} \mathrm{O}_{3} / \mathrm{C}$ tablets. The lattice parameter of Alon synthesized at $1650^{\circ} \mathrm{C}$ was found to be $0.7943 \mathrm{~nm}$ (from both $\mathrm{Al}_{2} \mathrm{O}_{3} / \mathrm{C}$ and wet-mixed $\mathrm{Al}_{2} \mathrm{O}_{3} / \mathrm{AlN}$ tablets), that of Alon synthesized at $1700^{\circ} \mathrm{C}$ from $\mathrm{Al}_{2} \mathrm{O}_{3} / \mathrm{C}$ tablets $0.7946 \mathrm{~nm}$.

The results from the experiment with alumina and carbon crucibles in the vertical tube furnace are given in Table 6 . As can be seen, the composition of the outside of the tablet reflects the stable phase under the chosen circumstances (if carbon is present, AIN is the stable phase, if alumina is used $\mathrm{Al}_{2} \mathrm{O}_{3}$ is the stable phase). At the same time the lattice

Table 5. Results from the experiments in the high frequency furnace: '+' indicates that Alon was found, '--' that it was not found. AIN was found in all experiments

\begin{tabular}{ccc}
\hline $\begin{array}{c}\text { Temperature } \\
\left({ }^{\circ} \mathrm{C}\right)\end{array}$ & $\mathrm{Al}_{2} \mathrm{O}_{3} / \mathrm{C}$ & $\mathrm{Al}_{2} \mathrm{O}_{3} / \mathrm{AlN}$ \\
\hline 1570 & - & \\
1580 & - & \\
1590 & - & \\
1600 & - & \\
1625 & - & - \\
1630 & - & + \\
1635 & + & \\
1650 & + & \\
1700 & - & \\
1800 & & \\
\hline
\end{tabular}


Table 6. Results from the sintering in the vertical tube furnace in an alumina or a carbon crucible

\begin{tabular}{|c|c|c|c|c|}
\hline \multirow[t]{2}{*}{ Crucible } & \multicolumn{2}{|c|}{ Outside } & \multicolumn{2}{|c|}{ Inside } \\
\hline & Phases & $\begin{array}{l}\text { Parameter } \\
(\mathrm{nm})\end{array}$ & Phases & $\begin{array}{c}\text { Parameter } \\
(\mathrm{nm})\end{array}$ \\
\hline $\begin{array}{l}\mathrm{Al}_{2} \mathrm{O}_{3} \\
\text { Graphitc }\end{array}$ & $\begin{array}{l}\text { Alon }+\mathrm{Al}_{2} \mathrm{O}_{3} \\
\text { Alon }+\mathrm{AIN}\end{array}$ & $\begin{array}{l}0.7938 \\
0.7942\end{array}$ & $\begin{array}{l}\text { Alon } \\
\text { Alon }\end{array}$ & $\begin{array}{l}0.7941 \\
0.7941\end{array}$ \\
\hline
\end{tabular}

parameter found on the inside of the tablet does not change.

The results from the experiments in the vertical tube furnace, the tungsten and the gas pressure furnace are summarized in Fig. 3(a) and Fig. 3(b) for temperature ranges $1650-1750^{\circ} \mathrm{C}$ and $1800-1850^{\circ} \mathrm{C}$ respectively. In the sintered tablets sometimes additional phases were present (see Fig. 3). At a temperature of $1600^{\circ} \mathrm{C}$ after $100 \mathrm{~h}$, no Alon was found. In these tablets, the ratio of $\mathrm{Al}_{2} \mathrm{O}_{3}$ and $\mathrm{AIN}$ was determined again (Fig. 4). On the horizontal axis the amount of aluminium oxide in the starting powder and on the vertical axis the amount determined with XRD after annealing $100 \mathrm{~h}$ at $1600^{\circ} \mathrm{C}$ is indicated. The solid line indicates no change in $\mathrm{Al}_{2} \mathrm{O}_{3} / \mathrm{AlN}$ ratio. As can be seen from this figure, the tablets have become somewhat richer in $\mathrm{Al}_{2} \mathrm{O}_{3}$ during the sintering. The observed composition shifts are only slightly larger than the un-

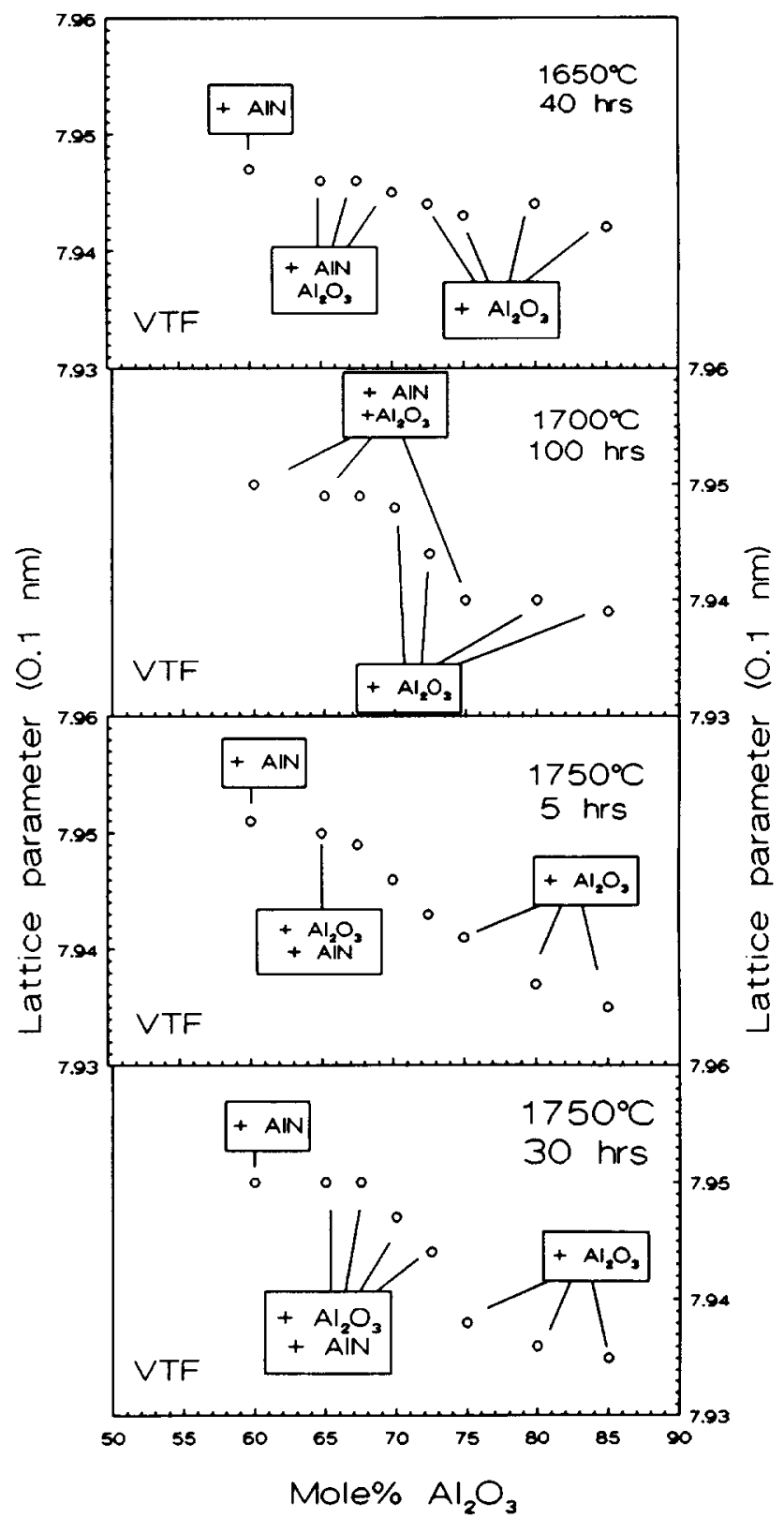

(a)

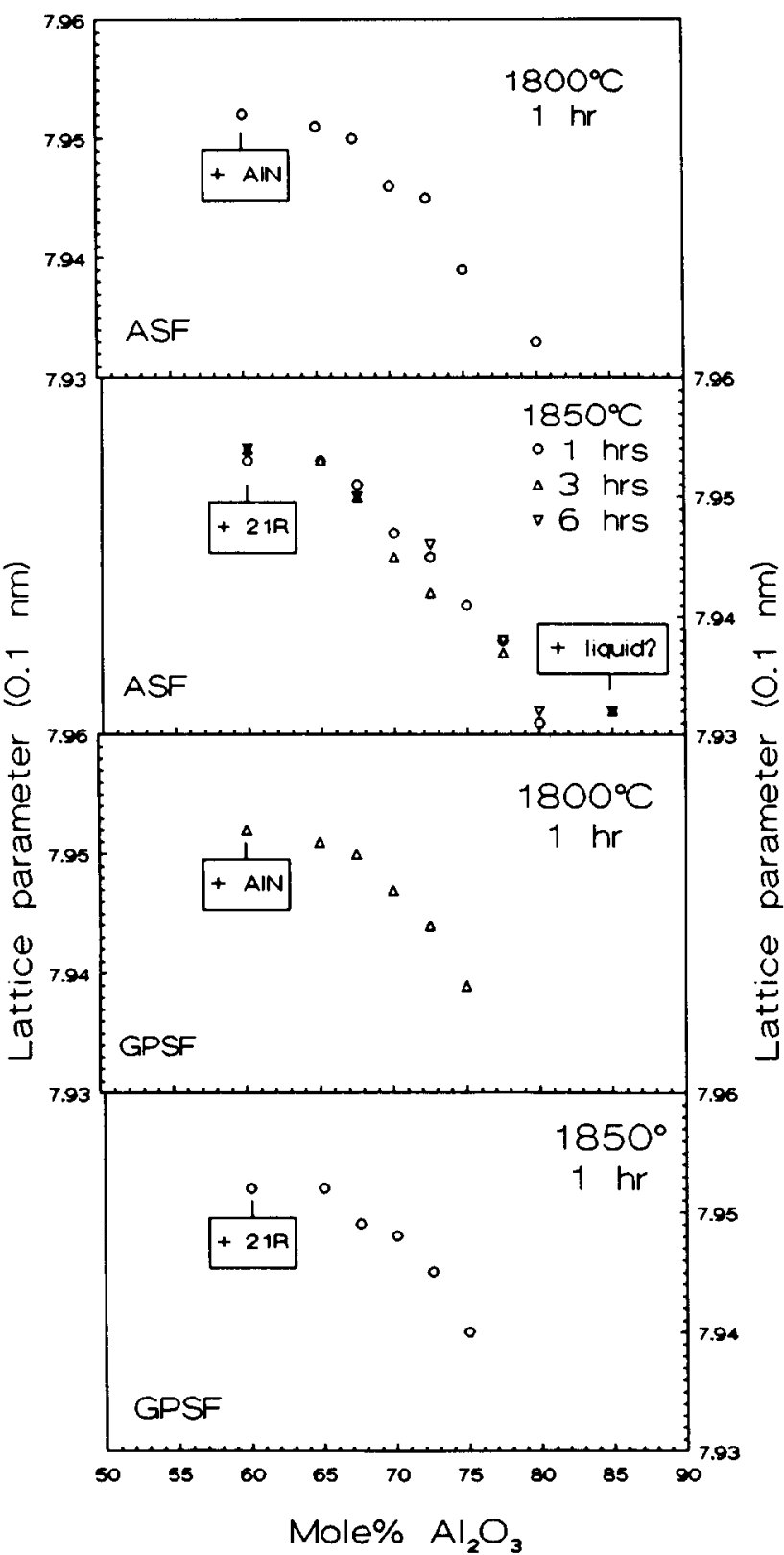

(b)

Fig. 3. Lattice parameter of Alon as a function of composition. The boxes indicate which other phases were present. The abbreviations in the lower left corner indicate the furnace used (cf. table 2). (a) Temperature region $1650-1750^{\circ} \mathrm{C}$; (b) temperature region $1800-1850^{\circ} \mathrm{C}$. 


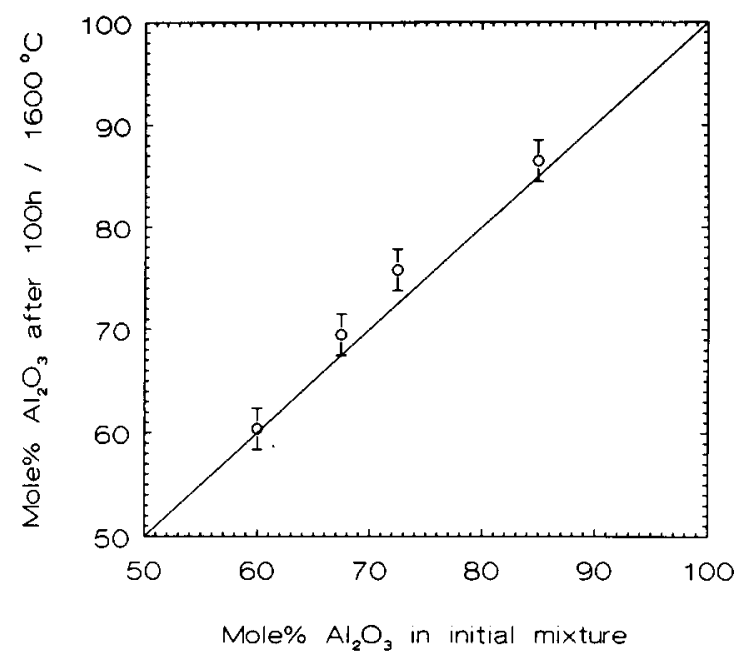

Fig. 4. $\mathrm{Al}_{2} \mathrm{O}_{3} / \mathrm{AIN}$ ratio after sintering for $100 \mathrm{~h}$ at $1600^{\circ} \mathrm{C}$. On the horizontal axis is the amount of aluminium oxide in the starting powder and on the vertical axis is the amount determined with XRD after annealing for $100 \mathrm{~h}$ at $1600^{\circ} \mathrm{C}$ is indicated. The solid line indicates no change in $\mathrm{Al}_{2} \mathrm{O}_{3} / \mathrm{AlN}$ ratio.

certainty in the measurements. The surface of the Alon sample annealed for $100 \mathrm{~h}$ in the horizontal tube furnace was completely converted to $\mathrm{AlN}$ and $\mathrm{Al}_{2} \mathrm{O}_{3}$ (about $55 \mathrm{~mol} \% \mathrm{Al}_{2} \mathrm{O}_{3}$ and $45 \mathrm{~mol} \% \mathrm{AlN}$ ).

Samples sintered in the tungsten furnace and the gas pressure furnace showed a weight loss of 1 to $2 \%$. The samples sintered in the gas pressure furnace (wet-mixed $\mathrm{Al}_{2} \mathrm{O}_{3} / \mathrm{AlN}$ tablets) and in the vertical tube furnace at $1750^{\circ} \mathrm{C}$ (dry-mixed $\mathrm{Al}_{2} \mathrm{O}_{3} / \mathrm{AlN}$ tablets) were slightly translucent when the composition was inside the homogeneity region.

If the results obtained at different temperatures are superimposed they fall into one pattern (Fig. 5). The thick line gives the relation between the composition and the lattice parameter (at all temperatures); the other lines show the maximum

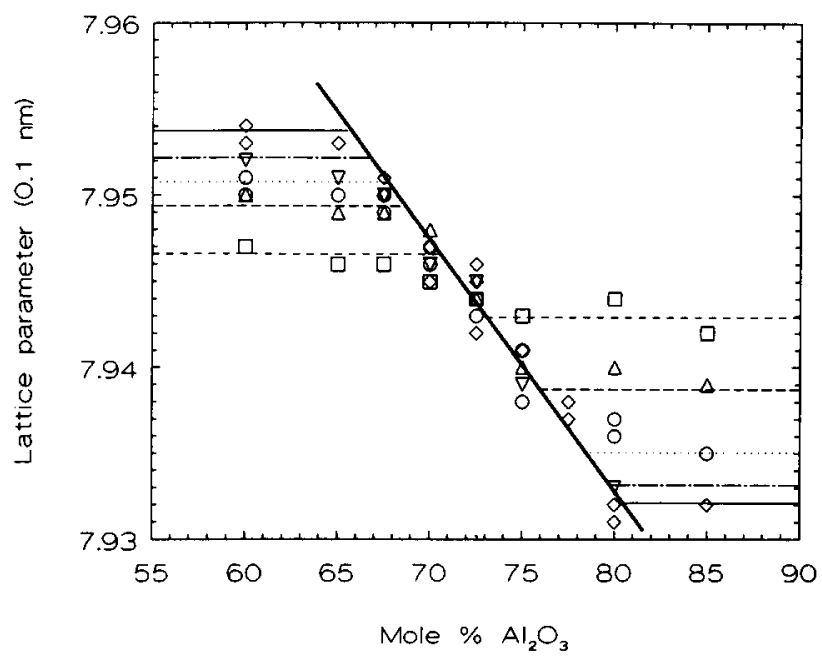

Fig. 5. Lattice parameter versus composition of Alon for various temperatures. $\square,--, 1650^{\circ} \mathrm{C} ; \triangle,---1700^{\circ} \mathrm{C} ; \mathrm{O}, \ldots$, $1750^{\circ} \mathrm{C} ; \nabla,--, 1800^{\circ} \mathrm{C} ; \diamond,-, 1850^{\circ} \mathrm{C}$

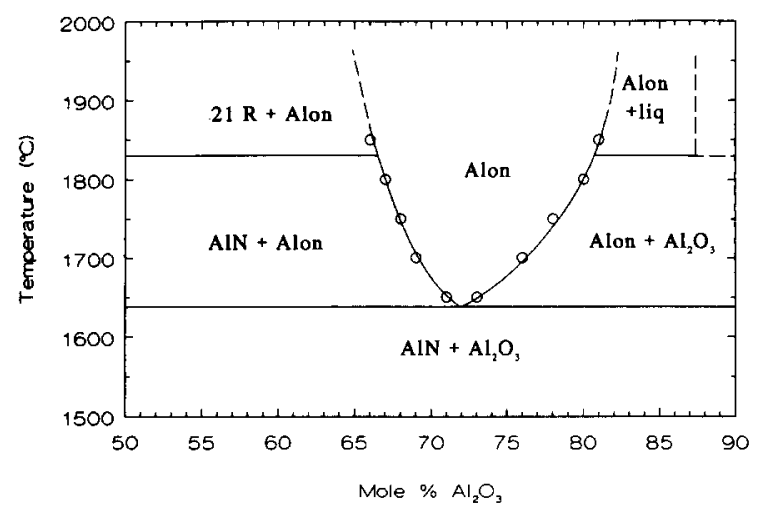

Fig. 6. The homogeneity region of Alon in the pseudobinary $\mathrm{Al}_{2} \mathrm{O}_{3}-\mathrm{AlN}$ system.

and the minimum lattice parameter attainable at the indicated temperature. If the range of compositions that lead to single-phase Alon is plotted against the temperature the shape of the homogeneity region of Alon in the pseudobinary $\mathrm{Al}_{2} \mathrm{O}_{3}-\mathrm{AlN}$ diagram (Fig. 6) can be found.

\section{Discussion}

There are a number of possible sources of error and these will be discussed in this section. The first item to discuss is the oxygen content of the AlN powder. According to the manufacturer, the AlN contained about $2.0 \mathrm{wt} \%$ of oxygen (an analysis of the batch used showed $1.8 \mathrm{wt} \%$ ). From the experiments it is clear that the samples lose weight during the sintering. This could be attributed to volatilization of $\mathrm{Al}_{2} \mathrm{O}$ (according to Corbin ${ }^{3}$ the most volatile species in his system). The oxygen content of the AlN powder and the oxygen loss by volatilization are then of the same order of magnitude. As it is not certain to which extent these reactions occur in reality, the authors choose not to take into account the oxygen content of the AlN powder nor the loss of oxygen by volatilization in the calculations regarding the composition of the samples. The maximum error made in this way is $\pm 0.5 \mathrm{~mol} \% \mathrm{Al}_{2} \mathrm{O}_{3}$.

As pointed out before, Alon is not stable under the reaction conditions. Therefore the compositions will tend to 'drift away' towards the more stable phase. Because the stable phase in these experiments is sometimes AlN (when graphite is present) and sometimes $\mathrm{Al}_{2} \mathrm{O}_{3}$ (when no reducing agent is present) and the results regarding the relation between the composition and the lattice parameter are the same in both cases, it is thought that in these experiments the composition shifts due to instability are not important at temperatures higher than $1700^{\circ} \mathrm{C}$. At lower temperatures the reaction times 


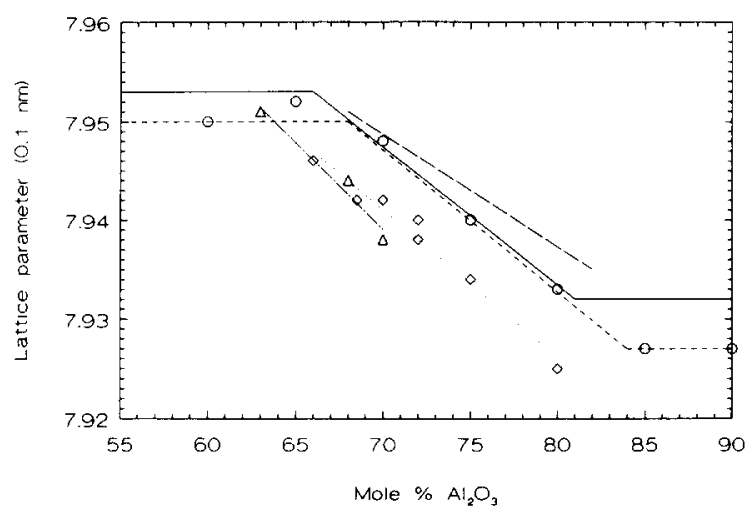

Fig. 7. Comparison of the lattice parameters from literature with the parameters found in this work. - This investigation; ..., Lejus; ${ }^{1} \ldots$... Guillo; ${ }^{3}$.... Takebe et al: $:^{4}--\ldots$, McCauley \& Corbin. ${ }^{9}$

are so long that some influence of the surroundings is inevitable. This can be seen in the changed ratio of $\mathrm{Al}_{2} \mathrm{O}_{3}$ and $\mathrm{AlN}$ in the samples sintered at $1600^{\circ} \mathrm{C}$ in the vertical tube furnace: some $\mathrm{Al}_{2} \mathrm{O}_{3}$ is formed during the process. Therefore it seems likely that the homogeneity region of Alon is artificially shifted towards the AlN side of the phase diagram (Fig. 7) for temperatures below $1750^{\circ} \mathrm{C}$. However, it is unlikely that this shift is more than a few atomic percent.

The form of the homogeneity region of Alon together with the fact that after $100 \mathrm{~h}$ at $1600^{\circ} \mathrm{C}$ no Alon is formed, while at $1650^{\circ} \mathrm{C}$ Alon is already formed after $1 \mathrm{~h}$ shows that Alon is not thermodynamically stable at the lower temperature. From Table 5 the lowest temperature at which Alon is stable is estimated to be $1640 \pm 10^{\circ} \mathrm{C}$. That Alon is not found at a temperature of $1800^{\circ} \mathrm{C}$ is due to the fast reaction at $1800^{\circ} \mathrm{C}$ : all $\mathrm{Al}_{2} \mathrm{O}_{3}$ is converted into AIN after $1 \mathrm{~h}$ (see, for instance, Ish-Shalom ${ }^{4}$ ).

Dry-mixed $\mathrm{Al}_{2} \mathrm{O}_{3} / \mathrm{AlN}$ tablets are not as homogeneous as wet-mixed $\mathrm{Al}_{2} \mathrm{O}_{3} / \mathrm{AlN}$ tablets, due to the inferior powder processing. As a result, it is more difficult to attain equilibrium with dry-mixed tablets than with wet-mixed tablets. For that reason the experiments in the vertical tube furnace (dry-mixed tablets) show more residual $\mathrm{Al}_{2} \mathrm{O}_{3}$ and/or $\mathrm{AlN}$ than the experiments in the tungsten furnace and the gas pressure furnace (wet-mixed tablets).

Because Alon is not stable below $1640^{\circ} \mathrm{C}$, it is possible that during the cooling down some reaction occurs backwards to $\mathrm{Al}_{2} \mathrm{O}_{3}$ and $\mathrm{AlN}$. The tungsten furnace and the gas pressure furnace have cooling rates of about $20^{\circ} \mathrm{C} \mathrm{min}^{-1}$ but the cooling rate of the vertical tube furnace is only about $3^{\circ} \mathrm{C} \mathrm{min}{ }^{-1}$. Therefore this backward reaction will be more important in the vertical tube furnace than in the tungsten furnace or the gas pressure furnace.
However, as the results from the two types of furnaces do not differ, the backward reaction, in the authors' opinion, has little or no effect on the results.

If the lattice parameters found in this work are compared with the parameters from the literature (Fig. 7), it can be seen that the present work agrees very well with the results from Lejus ${ }^{5}$ and reasonably with the results from Guillo. ${ }^{7}$ However, a few comments can be made. The temperature at which Lejus performed her experiments must have been higher than the claimed $1700^{\circ} \mathrm{C}$, because otherwise the width of her Alon region would not be so large. The results of Takebe et al ${ }^{8}$ give the same width of the region, but seem to contain some systematic error. The results from McCauley \& Corbin ${ }^{9}$ also show a deviation. Maybe this is due to the prereaction step they used: ${ }^{3}$ copper at $600^{\circ} \mathrm{C}$ is not able to bring about the very low oxygen pressure at which AlN is stable and consequently it is possible that some of their $\mathrm{AlN}$ was converted to $\mathrm{Al}_{2} \mathrm{O}_{3}$ in the prereaction step.

\section{Conclusion}

The width of the homogeneity region of Alon varies with temperature: at $1850^{\circ} \mathrm{C}$ Alon is the stable phase between $66 \mathrm{~mol} \% \mathrm{Al}_{2} \mathrm{O}_{3}$ (lattice parameter $0.7953 \mathrm{~nm}$ ) and $81 \mathrm{~mol} \% \mathrm{Al}_{2} \mathrm{O}_{3}$ (lattice parameter $0.7932 \mathrm{~nm}$ ). At lower temperatures the width of the region becomes smaller. Within the homogeneity region, the relation between the $\mathrm{Al}_{2} \mathrm{O}_{3} / \mathrm{AlN}$ ratio and the lattice parameter is the same for all temperatures but not all lattice parameters are attainable at all temperatures. Alon is not stable below $1640 \pm 10^{\circ} \mathrm{C}$.

\section{Acknowledgement}

The authors wish to thank Mr H. de Jonge Baas for recording the $\mathrm{X}$-ray diffraction patterns. This research has been partly sponsored by the Commission for the Innovative Research Program Technical Ceramics (IOP-TK) of the Ministry of Economic Affairs in the Netherlands (IOP-TK research grant 88.A022).

\section{References}

1. Willems, H. X., Hendrix, M. M. R. M., Metselaar, R. \& de With, G., Thermodynamics of Alon I: Stability at lower temperatures. J. Eur. Ceram. Soc., 10 (1992) 327-38. 
2. Cullity, B. D., Elements of $X$-ray diffraction. Addison Wesley, Reading, MA, 1956, pp. 324-43.

3. Corbin, N. D., The influence of carbon, nitrogen and argon on aluminium oxynitride spinel formation. MSc thesis, Massachusetts Institute of Technology, Cambridge, MA, 1982.

4. Ish-Shalom, M., Formation of aluminium oxynitride by carbothermal reduction of aluminiumoxide in nitrogen. $J$. Mater. Sci. Lett., 1 (1982) 147-9.

5. Lejus, A. M., Sur la formation a haute température de spinelles non stoechiométriques et de phases dérivées. Rev. Hautes Tempér. et Réfract., 1 (1964) 53-95.
6. McCauley, J. W., A simple model for aluminium oxynitride spinels. J. Am. Ceram. Soc., 61 (1978) 372.

7. Guillo, P., Thèse 32-85, Université de Limognes, 1985, cited in Corbin, N. D., Aluminium oxinitride spinel: a review. $J$. Eur. Ceram. Soc., 5 (1989) 143-54.

8. Takebe, H., Kameda, T., Komatsu, M., Komeya, K. \& Morinaga, K., Fabrication of translucent sintered aluminum oxynitride spinel (AlON). J. Ceram. Soc. Jpn Inter. Edn, 97 (1989) 163-9.

9. McCauley, J. W. \& Corbin, N. D., Phase relations and reaction sintering of transparent cubic aluminum oxynitride spinel (ALON). J. Am. Ceram. Soc., 62 (1979) 476-9. 